\title{
Faktor-Faktor yang Mempengaruhi Ukuran Urban Compactness di Kota Tangerang Selatan
}

\author{
Fara Zalsabilla dan Putu Gde Ariastita \\ Perencanaan Wilayah dan Kota, Fakultas Arsitektur Desain dan Perencanaan, \\ Institut Teknologi Sepuluh Nopember (ITS) \\ e-mail: ariastita@urplan.its.ac.id.com
}

\begin{abstract}
Abstrak-Compact city adalah suatu konsep perkotaan yang mengakomodasi kepadatan yang tinggi, penggunaan campuran, efisiensi sistem transportasi umum, dan upaya mendorong masyarakat untuk berjalan kaki dan bersepeda. Kota Tangerang Selatan merupakan kota Satelit baru dari Megapolitan Jabodetabek yang sudah menunjukan indikasi kekompakan ruang serta mendukung konsep perencanaan kota secara kompak. Namun, kekompakan ruang di Kota Tangerang Selatan belum optimal seiring dengan belum meratanya pembangunan pada tiap kecamatan dan tingginya arus komuter ke ibu kota. Penelitian ini bertujuan untuk mengidentifikasi faktor-faktor yang mempengaruhi urban compactness di Kota Tangerang Selatan. Dalam mengidentifikasi faktor-faktor tersebut digunakan dua tahapan analisis, yaitu identifikasi karakteristik kekompakan ruang Kota Tangerang Selatan dengen metode deskriptif kuantitatif dan dilanjutkan dengan analisis regresi linier berganda untuk menentukan faktorfaktor kekompakan ruang di Kota Tangerang Selatan. Hasil dari penelitian ini didapatkan empat faktor yang mempengaruhi ukuran urban compactness Kota Tangerang Selatan secara kuantitatif, yaitu kepadatan penduduk, kepadatan lahan terbangun, kepadatan permukiman serta tingkat penggunaan kendaraan umum. Hasil penelitian ini dapat digunakan sebagai acuan untuk merumuskan skenario serta kebijakan perencanaan kota Tangerang Selatan yang lebih compact.
\end{abstract}

Kata Kunci-Compact City, Indeks Urban Compactness, Perencanaan Perkotaan.

\section{PENDAHULUAN}

$\mathrm{C}$ OMPACT CITY diperkenalkan oleh George Dantzig dan Thomas L pada tahun 1973 sebagai bentuk kritik terhadap tidak efektifnya fenomena sprawl yang terjadi. Menurut Burton, terdapat tiga kata kunci dalam konsep kota kompak ini, yaitu densitas, konsentrasi (mixed use), dan intensifikasi. Dalam penerapannya kota kompak berkaitan erat dengan konsep kota berkelanjutan [1]. Kota Tangerang Selatan merupakan kota baru yang disahkan pada tahun 2008 dan menjadi salah satu kota satelit dari Ibu Kota DKI Jakarta. Hal ini ditandai oleh letak geografis Tangerang Selatan yang termasuk dalam lingkungan megapolitan Jabodetabek. Pembangunan kota-kota baru di Kota Tangerang Selatan dirintis dan dibangun secara terencana oleh pengembang besar (BSD, Bintaro Jaya, dan Alam Sutera) yang merupakan salah satu implementasi dari Instruksi Presiden No. 13 Tahun 1976 tentang Pengembangan Wilayah Jabotabek (Jakarta, Bogor, Tangerang dan Bekasi). Namun begitu juga muncul pusat-pusat pertumbuhan baru yang disebabkan oleh adanya sub-urbanisasi dari dampak perkembangan Kota Jakarta, terutama untuk daerah peri-urban Jakarta seperti Ciputat, Pamulang, dan Pondok Aren. Suburbanisasi yang terjadi cenderung menjadikan kawasan perkotaan menjadi kurang terstruktur dengan baik [2].
Oleh sebab itu, Tangerang Selatan juga merupakan salah satu kota yang sangat mempengaruhi dan dipengaruhi oleh fenomena urban sprawl yang terjadi di area Jabodetabek. Menurut data dari BPS Provinsi DKI Jakarta pada tahun 2014, terdapat 1.382.296 komuter dari BODETABEK yang berkegiatan di Jakarta setiap harinya. Hal ini didukung dengan fakta bahwa penduduk malam Jakarta yang hanya berjumlah 10.075.310 orang, sedangkan jumlah penduduk siang Jakarta mencapai 11.201.620 orang. Tangerang Selatan merupakan urutan ketiga dari penyumbang komuter ke DKI Jakarta setiap harinya yaitu 8,68 persen dari total presentase arus komuter Jabodetabek di dalam DKI Jakarta pada tahun 2014. Fakta diatas membuktikan bahwa Kota Tangerang Selatan merupakan salah satu area sub urban dari ibu kota yang sudah terkena dampak oleh fenomena pembangunan acak atau sprawl.

Berbagai permasalahan terkait fenomena sprawling yang dialami oleh Kota Tangerang Selatan sebagai area sub-urban dari DKI Jakarta diikuti dengan beberapa indikasi meningkatnya kekompakan kota di Tangerang Selatan. Seperti tingginya kepadatan penduduk di Tangerang yang mencapai $10.828 \mathrm{Jiwa} / \mathrm{Km}^{2}$. Hasil riset Lead Property Indonesia menunjukan bahwa benyak pengembang yang membangun bangunan vertikal di Kota Tangerang Selatan, hingga saat ini terdapat 1.500 Unit apartemen srata dan diperkirakan akan bertambah sebanyak 7.100 unit dalam 3 tahun ke depan. Fakta ini membuktikan adanya indikasi peningkatan penggunaan lahan dan intensifikasi di Kota Tangerang Selatan dimana hal tersebut termasuk ke dalam karakteristik utama dalam pembangunan kota kompak. Namun, dibalik kemajuan pembangunan dan indikasi kekompakan ruang yang dialami Kota Tangerang Selatan, Ketua Umum Ikatan Ahli perecana pada tahun 2015 berpendapat bahwa pembangunan di Tangerang Selatan belum merata dan lebih terfokus pada area-area pengembang swasta yang menjadi magnet industri dan perdagangan jasa seperti Serpong dan Serpong Utara.

Berdasarkan fakta permasalahan pembangunan kota dan munculnya gejala kekompakan ruang di Tangerang Selatan, konsep kota kompak dipercaya dapat menjadi solusi bagi perkembangan perkotaan yang lebih baik. Karena, secara teoritis kota kompak memiliki konsep pemadatan aktivitas di suatu perkotaan sehingga masyarakat dapat memenuhi kebutuhannya pada kota tersebut tanpa harus melakukan komuter yang akan mengakibatkan sparwling. Hal ini didukung oleh data dari Badan Pengelola Transportasi Jabodetabek atau BPTJ pada tahun 2017, Jabodetabek termasuk Tangerang Selatan harus berkonsep compact city untuk mendukung pemisahan konsep kota dan mengurangi beban Jakarta. Meski Jakarta sudah memiliki berbagai macam transportasi publik, kemacetan baru bisa teratasi 
apabila ada pemisahan fungsi perkotaan dengan meningkatkan kekompakan ruang. Mulai terbentuknya Tangerang Selatan sebagai compact city juga dibuktikan dengan masuknya kota Tangerang Selatan sebagai kota yang berkomitmen pada urban compact mayor dan Urban-LED yang didirikan UN Habitat untuk mendukung sistem kota berkelanjutan seperti compact city.

Hingga saat ini belum terdapat penelitian yang melakukan pengukuran faktor-faktor yang mempengaruh urban compactness di kota satelit baru seperti Tangerang Selatan. Oleh karena itu, Pada penelitian ini akan dirumuskan faktorfaktor urban compactness di Kota Tangerang Selatan guna mengetahui faktor-faktor yang dapat memengaruhi proses pengompakan ruang di Kota Tangerang Selatan.

\section{METODE PENELITIAN}

\section{A. Metode Pengumpulan Data}

Pengumpulan data pada penelitian ini dilakukan dengan metode primer dan sekunder. Survei data dengan metode sekunder dilakukan melalui studi literatur pada beberapa instansi pemerintahan seperti Badan Pusat Statistik Kota Tangerang Selatan, Bappeda Kota Tangerang Selatan, Dinas Tata Ruang Kota Tangerang Selatan. Sedangkan survei primer dilakukan dalam mengidentifikasi variabel tingkat penggunaan kendaraan umum melalui penyebaran kuesioner

\section{B. Unit analisis dan populasi penelitian}

Unit analisis wilayah penelitian ini mencakup keseluruhan 54 kelurahan yang ada di Kota Tangerang Selatan dengan menggunakan survey data sekunder. Survei primer dilakukan pada variabel tingkat kendaraan umum dengan propotional random sampling untuk mengetahui jumlah kuisioner yang akan disebarkan pada tiap kelurahan. Pada perhitungan sampel digunakan tingkat kesalahan 0,1. Sehingga, didapatkan jumlah minimal kuesioner yang disebarkan sejumlah 100 kuesioner untuk seluruh kelurahan yang ada di Kota Tangerang Selatan.

Namun, berdasarkan hasil pengamatan berdasarkan RTRW dan fakta dilapangan beberapa daerah di Tangerang Selatan mempunyai fungsi dan karakteristik yang sejenis dalam penataan ruang dan diikuti dengan penggunaan kendaraan. Sehingga penyebaran kuesioner dapat di wakilkan oleh satu daerah dengan karakteristik yang sejenis yaitu area CBD Tangerang Selatan dengan tiga kota mandiri yaitu Serpong, Serpong Utara dan Pondok Aren yang didalamnya terdapat BSD City, Alam Sutera dan Bintaro Jaya. Selanjutnya Area permukiman padat penduduk yang diwakilkan oleh Kecamatan Ciputat Timur dan Pamulang, area industri pada Kecamatan Setu dan area pusat pemerintahan pada Kecamatan Ciputat. Jumlah minimal penyebaran kuesioner pada setiap Kecamatan yang mewakili kelurahan dapat dilihat pada tabel berikut:

Tabel 1.

Jumlah Kuesioner

\begin{tabular}{|c|c|c|c|}
\hline No & Area & Kecamatan & Jml Kuesioner Minimal \\
\hline 1 & Central Business & Serpong & 46 \\
\hline 2 & District & Serpong Utara & \\
\hline 3 & & Pondok Aren & \\
\hline 4 & Permukiman Padat & Pamulang & 34 \\
\hline 5 & Penduduk & Ciputat Timur & \\
\hline 6 & Industri & Ciputat & 15 \\
\hline 7 & Pusat Pemerintahan & Setu & 5 \\
\hline
\end{tabular}

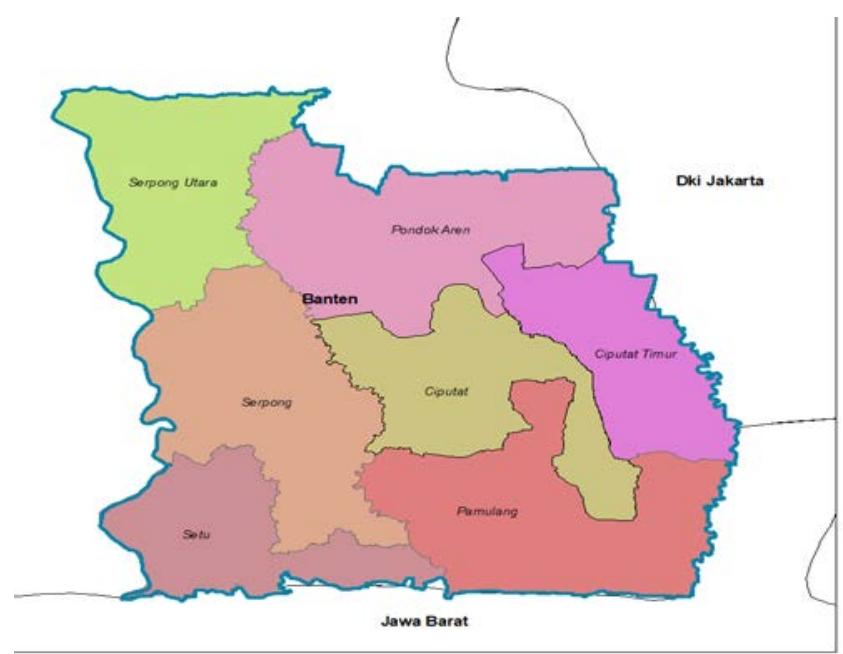

Gambar 1. Peta Ruang Lingkup Wilayah Kota Tangerang Selatan

\section{Variabel Penelitian}

Pada penelitian ini terdapat 3 indikator utama yang didapat dari sintersa indikator urban compactnesss dan faktor pembangunan kota satelit sebagai bagian dari kota baru yaitu kepadatan, fungsi campuran atau mixed use, dan intensifikasi. Berdasarkan hasil tinjauan pustaka dan pertimbangan dengan kondisi eksisting, maka dapat dirumuskan variabel-variabel kekompakan ruang di Kota Tangerang Selatan dapat dilihat pada tabel berikut

Tabel 2.

Variabel Penelitian

\begin{tabular}{ll}
\hline \hline \multicolumn{1}{c}{ Variabel } & \multicolumn{2}{c}{ Keterangan } \\
\hline Kepadatan & Variabel kepadatan penduduk diukur dengan \\
penduduk & menggunakan perbandingan jumlah penduduk setiap \\
(X1) & hektarnya. Variabel ini sangat relevan dengan \\
& indikator kota kompak yaitu kepadatan penduduk yang \\
& tinggi menandakan adanya pemadatan di suatu kota.
\end{tabular}

Kepadatan

lahan terbangun

(X2)

Kepadatan permukiman (X3)

Presentase
konsentrasi
luas lahan
terbangun
(X4)

Presentase

konsentrasi

luas lahan permukiman (X5)

Rasio ketersediaan fasilitas pendidikan (X6), perdagangan jasa (X7), kesehatan (X8)
Dimensi ini mengukur kepadatan penduduk pada lahan terbangun, pemadatan pada ruang terbangun dapat mengindikasikan bahwa terbentuk struktur kekompakan ruang dan semakin padat lahan terbangun maka semakin efisien pula pemanfaatan lahan sehingga lahan non terbangun dapat tetap terjaga dan menjadi konsep kota yang berkelanjutan

Dimensi ini mengukur kepadatan penduduk pada lahan permukiman, pemadatan pada ruang permukiman dapat mengindikasikan bahwa terbentuk struktur kekompakan ruang dan semakin padat lahan terbangun maka semakin efisien pula pemanfaatan lahan permukiman

Dimensi ini dapat memaparkan presentase luas lahan yang terbangun, dimensi ini dapat membantu melihat apakah lahan terbangun memiliki fungsi campuran atau tidak, kondisi pembangunan dengan fungsi campuran ini akan sangat medukung konsep kota kompak dengan kemudahan aksesbilitasnya.

Dimensi ini dapat memaparkan presentase luas lahan yang terbangun, dimensi ini dapat membantu melihat apakah lahan terbangun memiliki fungsi campuran atau tidak, kondisi pembangunan dengan fungsi campuran ini akan sangat medukung konsep kota kompak dengan kemudahan aksesbilitasnya.

Dimensi ini dapat memaparkan presentase luas lahan yang terbangun, dimensi ini dapat membantu melihat apakah lahan terbangun memiliki fungsi campuran atau tidak, kondisi pembangunan dengan fungsi campuran ini akan sangat medukung konsep kota kompak dengan kemudahan aksesbilitasnya. 


$\begin{array}{ll}\begin{array}{l}\text { Jumlah } \\ \text { pengguna } \\ \text { kendaraan } \\ \text { umum (X9) }\end{array} & \begin{array}{l}\text { Pertumbuhan penduduk yang tinggi setiap tahunnya } \\ \text { akan berpengaruh pada proses intensifikais yang } \\ \text { terjadi. }\end{array} \\ \begin{array}{l}\text { Laju } \\ \text { pertumbuhan } \\ \text { penduduk } \\ \text { (X10) }\end{array} & \begin{array}{l}\text { Jumlah pengguna kendaraan umum akan berpengaruh } \\ \text { pada proses pengkompakan ruang, karena pada }\end{array} \\ & \begin{array}{l}\text { pengguna kendaraan pribadi dengan cara } \\ \text { mengoptimalkan fungsi kendaraan umum dan }\end{array} \\ \text { memadatkan aktivitas pada suatu wiayah }\end{array}$

D. Menentukan faktor-faktor yang mempengaruhi urban compactness di Kota Tangerang Selatan

Analisis ini dilakukan melalui teknik analisa regresi linier berganda dengan metode stepwise dengan menggunalan 10 variabel independen dan indeks urban compactness sebagai variabel dependen. Tahap analisis ini bertujuan untuk mengetahui faktor-faktor apa saja yang terbukti secara kuantitatif mempengaruhi nilai urban compactness di Kota Tangerang Selatan.

\section{HASIL DAN PEMBAHASAN}

\section{A. Identifikasi Variabel kekompakan ruang Kota Tangerang} Selatan

\section{Kepadatan Lahan Terbangun (X1)}

Kepadatan penduduk pada penelitian ini dihitung dengan membagi jumlah penduduk (jiwa) dibagi dengan luas wilayah pada setiap kelurahan di Kota Tangerang Selatan Pada Kota Tangerang Selatan sendiri, terdapat beberapa kelurahan yang mempunyai kepadatan penduduk yang relatif tinggi seperti kelurahan-kelurahan yang berada pada Kecamatan Ciputat Timur, Pondok Aren dan Pamulang. Hal ini dapat disebabkan karena pada kelurahan-kelurahan seperti Pondok Benda, Rempoa dan Jurang Mangu terdapat permukiman berkepadatan tinggi. Sedangkan, Kelurahan-kelurahan seperti Lengkong Gudang, Muncul, Babakan yang mayoritas termasuk pada kecamatan Serpong dan Setu memiliki kepadatan penduduk yang rendah yang disebabkan karena masih rendahnya jumlah penduduk dan pembangunan permukiman di area tersebut

\section{Kepadatan Lahan Terbangun (X2)}

Salah satu indikator kekompakan ruang adalah tingginnya angka kepadatan area terbangun pada suatu wilayah [3]. Kepadatan Lahan Terbangun dilakukan perhitungan dengan membagi Jumlah penduduk (jiwa) dibagi dengan luas lahan terbangun (ha). Berdasarkan hasil perhitungan Kelurahan Serua yang berada pada Kecamatan Ciputat memiliki kepadatan lahan terbangun yang paling tinggi diikuti dengan kelurahan-kelurahan yang berada pada kecamatan Pamulang dan Pondok Aren yang memang tidak terlalu banyak lahan kosong maupun ruang terbuka hijau pada wilayahnya. Sedangkan area yang dikembangkan oleh pengembang swasta seperti BSD, Alam Sutera dan Bintaro yang terdapat pada kawasan Serpong, Serpong Utara dan beberapa kelurahan di Kecamatan Pondok Aren seperti Pondok Jaya dan Pondok Pucung memiliki kepadatan lahan terbangun yang relatif rendah. Hal ini dapat disebabkan karena beberapa area yang dimiliki oleh pengembang-pengembang tersebut masih dalam proses pembangunan, tipe permukiman real estate yang berkepadatan rendah dan diikuti banyaknya ruang terbuka hijau pada kawasan-kawasan tersebut.

\section{Kepadatan Lahan Permukiman (X3)}

Salah satu bentuk perkotaan dengan konsep compact adalah perkotaan yang memiliki permukiman berkepadatan tinggi [4]. Perhitungan area permukiman dilakukan dengan tidak membedakan tipe-tipe permukiman serta mengukur seluruh pola penggunaan lahan permukiman baik rumah kecil, sedang maupun besar. Kepadatan Permukiman dihitung dengan persamaan yaitu, Jumlah penduduk (jiwa) dibagi dengan luas lahan yang diperuntukan untuk permukiman (ha) pada setiap kelurahan di Kota Tangerang Selatan.

Permukiman dengan kepadatan tertinggi di Tangerang Selatan terletak pada kelurahan-kelurahan yang terletak pada Kecamatan Ciputat, Ciputat Timur dan Pamulang, dimana mayoritas perumahannya di dominasi oleh tipe rumah sedang dan kecil. Sedangkan, kelurahan-kelurahan di Kecamatan Setu, Serpong dan Serpong Utara memiliki kepadatan permukiman yang relatif sangat rendah hingga sedang, hal ini dapat diakibatkan karena beberapa area pada kawasan tersebut masih dalam tahap pembangunan dan tipe rumah yang relatif sedang hingga besar.

Tabel 3.

Hasil Identifikasi Indikator Kepadatan

\begin{tabular}{|c|c|c|c|}
\hline Kelurahan & X1 & $\mathrm{X} 2$ & X3 \\
\hline Serua & 96.41 & 139.80 & 149.33 \\
\hline Jombang & 129.76 & 188.46 & 209.31 \\
\hline Sawah Baru & 126.81 & 172.14 & 225.19 \\
\hline Serua Indah & 75.40 & 154.58 & 165.98 \\
\hline Sawah Lama & 118.15 & 180.85 & 200.13 \\
\hline Ciputat & 152.49 & 209.24 & 305.61 \\
\hline Cipayung & 87.37 & 129.44 & 147.61 \\
\hline Pisangan & 102.95 & 128.83 & 151.26 \\
\hline Cireundeu & 104.62 & 134.68 & 153.74 \\
\hline Cempaka Putih & 136.96 & 172.37 & 217.65 \\
\hline Rempoa & 169.08 & 184.19 & 230.24 \\
\hline Rengas & 99.83 & 116.74 & 120.58 \\
\hline Pondok Ranji & 113.48 & 156.31 & 172.86 \\
\hline Pondok Benda & 184.25 & 238.79 & 248.69 \\
\hline Pamulang Barat & 133.74 & 160.97 & 193.80 \\
\hline Pamulang Timur & 139.70 & 187.55 & 206.69 \\
\hline Pondok Cabe Udik & 46.02 & 76.29 & 124.57 \\
\hline Pondok Cabe Ilir & 109.47 & 156.85 & 340.30 \\
\hline Kedaung & 214.71 & 239.78 & 244.73 \\
\hline Bambu Apus & 136.31 & 216.28 & 224.93 \\
\hline Benda Baru & 91.03 & 128.20 & 136.66 \\
\hline Perigi Baru & 41.79 & 128.44 & 146.79 \\
\hline Pondok Kacang Barat & 107.40 & 178.74 & 188.67 \\
\hline Pondok Kacang Timur & 172.95 & 223.97 & 231.61 \\
\hline Parigi & 56.91 & 86.46 & 110.64 \\
\hline Pondok Pucung & 116.00 & 135.25 & 151.13 \\
\hline Pondok Jaya & 59.20 & 70.85 & 140.87 \\
\hline Pondok Aren & 139.39 & 162.67 & 170.00 \\
\hline Jurang Mangu Barat & 179.17 & 198.60 & 206.54 \\
\hline Jurang Mangu Timur & 195.76 & 225.29 & 259.66 \\
\hline Pondok Karya & 198.10 & 227.69 & 260.58 \\
\hline Pondok Betung & 203.87 & 231.92 & 252.27 \\
\hline Buaran & 48.52 & 114.11 & 125.92 \\
\hline Ciater & 60.68 & 149.41 & 172.63 \\
\hline Rawa Mekar Jaya & 59.96 & 88.28 & 106.89 \\
\hline Rawa Buntu & 89.21 & 99.88 & 124.02 \\
\hline Serpong & 97.12 & 143.33 & 179.75 \\
\hline Cilennggang & 47.18 & 69.07 & 87.13 \\
\hline Lengkong Gudang & 44.43 & 54.45 & 84.77 \\
\hline Lengkong Gudang Timur & 41.07 & 63.66 & 74.75 \\
\hline Lengkong Wetan & 57.04 & 105.20 & 172.59 \\
\hline Lengkong Karya & 24.03 & 38.06 & 78.96 \\
\hline Jelupang & 84.23 & 112.84 & 121.36 \\
\hline Pondok Jagung & 119.70 & 153.46 & 180.10 \\
\hline Pondok Jagung Timur & 107.05 & 147.98 & 159.97 \\
\hline Pakulonan & 61.60 & 71.87 & 140.70 \\
\hline Paku Alam & 56.65 & 85.55 & 143.50 \\
\hline Pakujaya & 103.43 & 168.38 & 213.14 \\
\hline
\end{tabular}




\begin{tabular}{lrrr} 
Keranggan & 24.84 & 107.08 & 116.60 \\
Muncul & 24.69 & 47.10 & 138.34 \\
Kademangan & 112.80 & 178.89 & 202.93 \\
Setu & 36.32 & 51.17 & 92.62 \\
Babakan & 32.24 & 60.08 & 68.43 \\
Bakti Jaya & 104.05 & 193.19 & 198.28 \\
\hline
\end{tabular}

4. Presentase Konsentrasi Luas Lahan Terbangun (X4)

Konsentrasi lahan terbangun dapat melihat perbandingan lahan kosong dan lahan terbangun pada suatu wilayah. Dengan mengetahui konsentrasi lahan terbangun dapat mebantu melihat tingkat keefektifan penggunaan lahan pada suatu wilayah. Variabel ini dihitung dengan membagi luas lahan terbangun (ha) dengan total luas wilayah (ha) per kelurahan di Kota Tangerang Selatah dan dikalikan dengan $100 \%$

Pada Kota Tangerang Selatan sendiri, konsentrasi lahan terbangun paling tinggi diduduki oleh kelurahan-kelurahan pada Kecamatan Pondok Aren. Diikuti dengan beberapa kelurahan seperti Rawa Buntu, Pamulang Barat dan Pakulonan. Sedangkan konsentrasi lahan terbangun terendah berada di beberapa kelurahan pada Kecamatan Setu.

\section{Presentase Konsentrasi Luas Lahan Permukiman (X5)}

Konsentrasi lahan permukiman yang tinggi pada suatu perkotaan akan mempengaruhi jumlah penggunaan lahan campuran dan kepadatan aktivitas dalam suatu perkotaan. Variabel ini dihitung dengan membagi luas lahan permukiman (ha) dengan total luas wilayah (ha) per kelurahan di Kota Tangerang Selatah dan dikalikan dengan $100 \%$.

Menurut hasil perhitungan, kelurahan Kedaung, Pondok Benda dan kelurahan-kelurahan yang berada pada Kecamatan Pondok Aren memiliki tingkat konsentrasi lahan permukiman tertinggi di Tangerang Selatan yaitu sekitar 70\% dari total luas wilayah. Sedangkan, beberapa kelurahan di Kecamatan Serpong dan Setu memiliki konsentrasi lahan permukiman terendah yaitu sekitar 30\% dari total luas wilayah.

\section{Rasio ketersediaan Fasilitas Pendidikan (X6)}

Ketersediaan dan keterjangkauan fasilitas pelayanan skala lokal merupakan salah satu indikator dalam konsep kota kompak, termasuk diantaranya fasilitas pendidikan. Pada kota Tangerang Selatan fasilitas pendidikan diukur dengan membandingkan ketersediaan unit SD, SMP dan SMA dengan standar SNI 03-1773-2004 tentang Tata Cara Perencanaan Lingkungan Perumahan di Perkotaan, lalu dikalikan $100 \%$. Standar ketersediaan pendidikan yang tercantum pada peraturan tersebut adalah, 1 SD untuk 1.600 penduduk, 1 SMP untuk 4.800 penduduk, serta 1 SMA untuk 4.800 penduduk.

Berdasarkan hasil perhitungan rasio ketersediaan fasilitas pendidikan di kelurahan-kelurahan Kota Tangerang Selatan cenderung masih rendah. Secara keseluruhan hanya ada empat kelurahan yang memiliki tingkat ketersediaan fasilitas pendidikan yang terbilang cukup tinggi di kota ini yaitu Kelurahan Ciputat, Parigi, Cilenggang, Rawa Buntu. Rendahnya ketersediaan fasilitas pendidikan dapat berbanding lurus dengan kecenderungan masyarakat Tangerang Selatan yang menempuh pendidikan di luar area Tangerang Selatan. Sehingga, hal tersebut dapat menjadi salah satu pendorong adanya gejala-gejala sprawling di Kota Tangerang Selatan.

\section{Rasio ketersediaan Fasilitas Perdagangan dan Jasa} (X7)

Keterjangkauan akses untuk meminimalisir penggunaan kendaraan dan ketersediaan fasilitas perdagangan jasa adalah salah satu tujuan dari konsep compact city. Selain itu, tingginya perdagangan jasa pada suatu perkotaan dapat mendukung salah satu dari faktor ekonomi kota satelit yaitu terbukanya kesempatan kerja baru dan penururnan beban kota-kota besar. Perhitungan fasilitas perdagangan dan jasa di Kota Tangerang Selatan didasarkan pada standar SNI 031773-2004 tentang Tata Cara Perencanaan Lingkungan Perumahan di Perkotaan. Standart ketersediaan perdagangan jasa sesuai peraturan yang berlaku adalah $0,3 \mathrm{~m}^{2} /$ jiwa.

Dari hasil perhitungan beberapa kelurahan yang memiliki tingkat ketersediaan cukup baik ada di Kecamatan Serpong, Serpong Utara, Pondok Aren dan Ciputat dimana beberapa area tersebut adalah area CBD Tangerang Selatan yang dikembangkan oleh pengembang-pengembang swasta. Namun, sebagian besar angka ketersediaan fasilitas perdagangan jasa pada tiap kelurahan di Kota Tangerang Selatan masih pada tingkat yang relatif rendah, sehingga masih dibutuhkan konsep pengompakan ruang Kota Tangerang Selatan.

\section{Rasio ketersediaan Fasilitas Kesehatan (X8)}

Salah satu tujuan dari konsep kota kompak adalah peningkatan kualitas hidup kota [5]. Peningkatan kualitas hidup kota dapat terwujud dengan tersedianya fasilitas kesehatan yang dapat dijangkau oleh seluruh masyarakat perkotaan dengan mudah. Pada penelitian ini fasilitas kesehatan diukur dengan membandingkan ketersediaan unit Posyandu, Puskesmas, RS Bersalin dan Praktek Dokter pada skala kelurahan dengan standar SNI 03-1773-2004 tentang Tata Cara Perencanaan Lingkungan Perumahan di Perkotaan, lalu dikalikan $100 \%$. Standart ketersediaan ketersediaan yang tercantum pada peraturan tersebut adalah satu Posyandu untuk 1.250 penduduk, satu Puskesmas untuk 30.000 penduduk, satu praktek dokter untuk 5.000 penduduk dan satu RS bersalin untuk 30.000 penduduk.

Berdasarkan hasil perhitungan dan survei sekunder, ketersediaan fasilitas kesehatan di Kota Tangerang Selatan belum merata jika dilihat dari ketersediaan posyandu, puskesmas, RS Bersalin maupun praktek dokter. Beberapa kelurahan bahkan tidak memiliki puskesmas sama sekali. Beberapa kelurahan yang memiliki rasio ketersediaan paling tinggi di Kota Tangerang Selatan diantaranya Serpong, Pakualam, Pondok Jangung dan Kranggan.

Tabel 3.

Hasil Identifikasi Indikator Penggunaan Campuran

\begin{tabular}{lcccrc}
\hline \multicolumn{1}{c}{ Kelurahan } & X4 & X5 & X6 & \multicolumn{1}{c}{ X7 } & X8 \\
\hline Serua & 0.69 & 0.65 & 0.49 & 2.52 & 0.71 \\
Jombang & 0.69 & 0.62 & 0.30 & 2.80 & 0.74 \\
Sawah Baru & 0.74 & 0.56 & 0.16 & 0.41 & 0.48 \\
Serua Indah & 0.49 & 0.45 & 0.26 & 4.38 & 1.16 \\
Sawah Lama & 0.65 & 0.59 & 0.16 & 4.44 & 0.68 \\
Ciputat & 0.73 & 0.50 & 0.92 & 22.59 & 1.41 \\
Cipayung & 0.67 & 0.59 & 0.25 & 18.30 & 0.47 \\
Pisangan & 0.80 & 0.68 & 0.33 & 7.10 & 0.83 \\
Cireundeu & 0.78 & 0.68 & 0.33 & 7.65 & 0.29 \\
Cempaka Putih & 0.79 & 0.63 & 0.29 & 17.46 & 0.49 \\
Rempoa & 0.92 & 0.73 & 0.24 & 2.89 & 0.59 \\
Rengas & 0.86 & 0.83 & 0.00 & 1.75 & 0.52 \\
Pondok Ranji & 0.73 & 0.66 & 0.27 & 0.82 & 0.36 \\
Pondok Benda & 0.77 & 0.74 & 0.37 & 0.78 & 1.08 \\
Pamulang Barat & 0.83 & 0.69 & 0.58 & 8.23 & 1.12 \\
Pamulang Timur & 0.74 & 0.68 & 0.13 & 2.26 & 0.18 \\
Pondok Cabe Udik & 0.60 & 0.37 & 0.54 & 49.25 & 0.58 \\
Pondok Cabe Ilir & 0.70 & 0.32 & 0.27 & 86.71 & 0.28 \\
Kedaung & 0.90 & 0.88 & 0.22 & 0.53 & 0.50 \\
Bambu Apus & 0.63 & 0.61 & 0.14 & 0.89 & 0.50 \\
Benda Baru & 0.71 & 0.67 & 0.32 & 2.88 & 1.47 \\
Perigi Baru & 0.33 & 0.28 & 0.48 & 3.16 & 1.22 \\
Pondok Kacang Barat & 0.60 & 0.57 & 0.24 & 0.23 & 0.84 \\
Pondok Kacang Timur & 0.77 & 0.75 & 0.26 & 0.16 & 0.54 \\
Parigi & 0.66 & 0.51 & 0.94 & 8.20 & 0.56
\end{tabular}




\begin{tabular}{llllrl} 
Pondok Pucung & 0.86 & 0.77 & 0.24 & 2.21 & 0.68 \\
Pondok Jaya & 0.84 & 0.42 & 0.67 & 76.62 & 1.67 \\
Pondok Aren & 0.86 & 0.82 & 0.37 & 1.22 & 0.84 \\
Jurang Mangu Barat & 0.90 & 0.87 & 0.24 & 1.16 & 0.53 \\
Jurang Mangu Timur & 0.87 & 0.75 & 0.17 & 2.31 & 0.58 \\
Pondok Karya & 0.87 & 0.76 & 0.31 & 9.53 & 0.37 \\
Pondok Betung & 0.88 & 0.81 & 0.12 & 1.83 & 0.63 \\
Buaran & 0.43 & 0.39 & 0.29 & 3.34 & 0.34 \\
Ciater & 0.41 & 0.35 & 0.17 & 8.30 & 1.65 \\
Rawa Mekar Jaya & 0.68 & 0.56 & 0.35 & 16.02 & 0.62 \\
Rawa Buntu & 0.89 & 0.72 & 0.74 & 19.88 & 0.44 \\
Serpong & 0.68 & 0.54 & 0.41 & 6.75 & 2.07 \\
Cilennggang & 0.68 & 0.54 & 0.99 & 1.39 & 0.33 \\
Lengkong Gudang & 0.82 & 0.52 & 0.31 & 63.83 & 0.66 \\
Lengkong Gudang Timur & 0.65 & 0.55 & 0.32 & 18.38 & 0.89 \\
Lengkong Wetan & 0.54 & 0.33 & 0.39 & 2.56 & 1.08 \\
Lengkong Karya & 0.63 & 0.30 & 0.17 & 142.21 & 0.69 \\
Jelupang & 0.75 & 0.69 & 0.41 & 0.55 & 1.22 \\
Pondok Jagung & 0.78 & 0.66 & 0.35 & 15.60 & 2.40 \\
Pondok Jagung Timur & 0.72 & 0.67 & 0.13 & 3.16 & 0.68 \\
Pakulonan & 0.86 & 0.44 & 0.32 & 110.38 & 0.72 \\
Paku Alam & 0.66 & 0.39 & 0.27 & 53.19 & 2.16 \\
Pakujaya & 0.61 & 0.49 & 0.08 & 8.00 & 0.22 \\
Keranggan & 0.23 & 0.21 & 0.51 & 0.00 & 2.26 \\
Muncul & 0.52 & 0.18 & 0.36 & 0.00 & 1.34 \\
Kademangan & 0.63 & 0.56 & 0.12 & 2.03 & 0.46 \\
Setu & 0.71 & 0.39 & 0.48 & 10.03 & 0.66 \\
Babakan & 0.54 & 0.47 & 0.14 & 12.30 & 1.35 \\
Bakti Jaya & 0.54 & 0.52 & 0.18 & 1.95 & 0.79 \\
\hline \hline
\end{tabular}

9. Tingkat Penggunaan Kendaraan Umum

Salah satu ciri dari diterapkannya konsep kota kompak adalah diutamakannya penggunaan kendaraan umum, sepeda dan berjalan kaki dikarenakan adanya transportasi umum yang lebih baik dan skala kota yang mudah dicapai bagi semua moda transportasi [5]. Data pada variabel penggunaan kendaraan umum didapatkan dengan cara penyebaran kuisioner dengan metode propotional random sampling dengan tingkat kesalahan $10 \%$. Sedangkan, presentase tingkat penggunaan kendaraan umum dihitung dengan membagi jumlah sampel pengguna kendaraan umum dengan seluruh sampel lalu di konversikan menjadi bentuk persen dengan dikalikan 100. Berdasarkan hasil perhitungan tingkat penggunaan kendaraan umum di Kota Tangerang Selatan cenderung sangat rendah dengan nilai yang hanya berkisar antara 16-33 persen dari total seluruh pengguna kendaraan.

10. Laju Pertumbuhan Penduduk

Intensifikasi penduduk merupakan salah satu indikator utama kekompakan ruang, kepadatan yang tinggi dan pertumbuhan penduduk ke bagian dalam kota dapat menjadi ciri adanya pengompakan ruang di wilayah tersebut. Secara keseluruhan laju pertumbuhan penduduk cenderung tinggi di Tangerang Selatan, terutama pada area Serpong, Serpong Utara dan Pondok Aren. Hal tersebut dapat dipengaruhi oleh tingginya minat investor swasta untuk mengembangkan kawasan tersebut menjadi pusat kegiatan perekonomian Kota Tangerang Selatan, sehingga muncul perumahan-perumahan baru berupa real estate yang memancing masyarakat untuk bertempat tinggal di area tersebut. Laju pertumbuhan penduduk Kota Tangerang Selatan dihitung dengan, jumlah penduduk pada tahun terakhir (2016) dikurangi dengan jumlah penduduk pada kurun waktu lima tahun sebelumnya (2012) dibagi dengan jumlah penduduk tahun 2012 (jiwa/ha) dikali $100 \%$.

\section{Indeks Urban Compactness}

Pada beberapa penelitian terdahulu telah dilakukan perhitungan kuantitatif untuk mendeskripsikan kekompakan ruang suatu wilayah. Pada penelitian ini, indeks urban compactness diukur dengan metode kuantifikasi yang dilakukan oleh D. Stahakis dan G. Tsilikmigkas [6]. Indeks urban compactness didapatkan dengan cara menstandarisasi kombinasi antara indeks densifikasi/kepadatan dengan indeks mixed use. Hasil perhitungan dari indeks urban compactness nantinya akan digunakan sebagai variabel $\mathrm{Y}$ atau variabel dependen pada sasaran pertama penelitian yaitu uji regresi linier berganda. Rumus perhitungan indeks urban compactness pada Kota Tangerang Selatan adalah :

Indeks Densifikasi $=$

Kepadatan Pend. + Kepadatan Permukiman + Kepadatan Lahan Terbangun

Indeks Mixed Use =

Luas Lahan Permukiman

$\overline{\text { Luas Lahan Terbangun - Luas Lahan Permukiman }}$

Indeks Urban Compactness $=$

Indeks Densifikasi + Indeks Mixed Use

2

Tabel 3.

Hasil Identifikasi Indikator Intensifikasi dan Indeks UC

\begin{tabular}{|c|c|c|c|}
\hline Kelurahan & X9 & X10 & Indeks UC (Y) \\
\hline Serua & 0.33 & 0.11 & 71.58995726 \\
\hline Jombang & 0.33 & 0.15 & 92.44091134 \\
\hline Sawah Baru & 0.33 & 0.19 & 88.97891536 \\
\hline Serua Indah & 0.33 & 0.11 & 72.77162719 \\
\hline Sawah Lama & 0.33 & 0.15 & 87.87993761 \\
\hline Ciputat & 0.33 & 0.03 & 112.3090702 \\
\hline Cipayung & 0.33 & 0.05 & 64.2984201 \\
\hline Pisangan & 0.21 & 0.08 & 66.71214105 \\
\hline Cireundeu & 0.21 & 0.11 & 69.0397154 \\
\hline Cempaka Putih & 0.21 & 0.04 & 89.73373592 \\
\hline Rempoa & 0.21 & 0.05 & 99.25300404 \\
\hline Rengas & 0.21 & 0.05 & 71.37809094 \\
\hline Pondok Ranji & 0.21 & 0.15 & 78.49843599 \\
\hline Pondok Benda & 0.21 & 0.10 & 124.0109437 \\
\hline Pamulang Barat & 0.21 & 0.11 & 83.8701427 \\
\hline Pamulang Timur & 0.21 & 0.14 & 93.89040659 \\
\hline Pondok Cabe Udik & 0.21 & 0.13 & 41.9346199 \\
\hline Pondok Cabe Ilir & 0.21 & 0.09 & 101.531475 \\
\hline Kedaung & 0.21 & 0.04 & 140.7868502 \\
\hline Bambu Apus & 0.21 & 0.23 & 108.7546003 \\
\hline Benda Baru & 0.21 & 0.10 & 66.88738624 \\
\hline Perigi Baru & 0.26 & 0.16 & 56.33474881 \\
\hline Pondok Kacang Barat & 0.26 & 0.22 & 88.13398138 \\
\hline Pondok Kacang Timur & 0.26 & 0.07 & 119.4220401 \\
\hline Parigi & 0.26 & 0.20 & 44.12288345 \\
\hline Pondok Pucung & 0.26 & 0.14 & 71.32377993 \\
\hline Pondok Jaya & 0.26 & 0.10 & 45.65892476 \\
\hline Pondok Aren & 0.26 & 0.17 & 89.7763079 \\
\hline Jurang Mangu Barat & 0.26 & 0.16 & 109.8852075 \\
\hline Jurang Mangu Timur & 0.26 & 0.13 & 116.7288432 \\
\hline Pondok Karya & 0.26 & 0.24 & 117.8583973 \\
\hline Pondok Betung & 0.26 & 0.06 & 120.3765869 \\
\hline Buaran & 0.26 & 0.09 & 52.92556798 \\
\hline Ciater & 0.26 & 0.14 & 67.00379639 \\
\hline Rawa Mekar Jaya & 0.26 & 0.16 & 44.89317325 \\
\hline Rawa Buntu & 0.26 & 0.15 & 54.25331081 \\
\hline Serpong & 0.26 & 0.09 & 72.00182144 \\
\hline Cilennggang & 0.26 & 0.06 & 35.80841709 \\
\hline Lengkong Gudang & 0.26 & 0.17 & 31.50774382 \\
\hline Lengkong Gudang Timur & 0.26 & 0.12 & 32.78407292 \\
\hline Lengkong Wetan & 0.26 & 0.09 & 56.58579748 \\
\hline Lengkong Karya & 0.26 & 0.17 & 23.97458869 \\
\hline Jelupang & 0.26 & 0.24 & 59.69658358 \\
\hline Pondok Jagung & 0.26 & 0.14 & 78.42489805 \\
\hline Pondok Jagung Timur & 0.26 & 0.40 & 75.33361496 \\
\hline Pakulonan & 0.26 & 0.13 & 46.21878325 \\
\hline Paku Alam & 0.26 & 0.04 & 48.3542655 \\
\hline Pakujaya & 0.26 & 0.23 & 82.70647111 \\
\hline Keranggan & 0.16 & -0.03 & 47.04550504 \\
\hline Muncul & 0.16 & 0.07 & 35.27892099 \\
\hline Kademangan & 0.16 & 0.22 & 86.1592059 \\
\hline Setu & 0.16 & 0.20 & 30.63595355 \\
\hline Babakan & 0.16 & -0.03 & 30.38509024 \\
\hline Bakti Jaya & 0.16 & 0.02 & 101.5869885 \\
\hline
\end{tabular}




\section{B. Faktor-faktor yang mempengaruhi ukuran urban compactness Kota Tangerang Selatan}

Pada tahap analisis regresi linier berganda, variabel independen yang digunakan adalah nilai kepadatan penduduk (X1), kepadatan lahan terbangun (X2), kepadatan permukiman (X3), presentase konsentasi lahan terbangun (X4), presentase konsentrasi luas lahan permukiman (X5), rasio ketersediaan fasilitas pendidikan (X6), rasio ketersediaan fasilitas perdagangan jasa (X7), rasio ketersediaan fasilitas kesehatan (X8), tingkat penggunaan kendaraan umum (X9) dan laju pertumbuhan penduduk (X10). Variabel dependen (Y) yang digunakan adalah nilai dari indeks urban compactness masing-masing kelurahan yang ada di Kota Tangerang Selatan. Setalah melalui uji asumsi klasik seluruh varriabel telah terbukti memenuhi kriteria uji normalitas, multikolineraritas, uji keterogenitas dan autokorelasi. Berikut adalah model regresi yang dapat menginterpretasikan faktor-faktor yang secara signifikan mempengaruhi ukuran urban compactness di Kota Tangerang Selatan:

$Y=-8,01+0,54(X 1)+0,29(X 2)+0,18(X 3)-0,04(X 9)$

Keterangan :

Y : nilai indeks urban compactness Kota Tangerang Selatan

X1 : Kepadatan Penduduk

X2 : Kepadatan Lahan Terbangun

X3 : Kepadatan Lahan Permukiman

X9 : Tingkat Penggunaan Kendaraan Umum

Berdasarkan hasil uji linier berganda yang dilakukan, dapat dilihat terdapat empat faktor yang mampu menjelaskan nilai kekompakan ruang Kota Tangerang Selatan yaitu Kepadatan Penduduk, Kepadatan Lahan Terbangun, Kepadatan Lahan Permukiman dan Tingkat Penggunaan Kendaraan Umum. Faktor-faktor tersebut mampu menjelaskan nilai urban compactness Kota Tangerang Selatan dengan presentase sebesar 98\% sesuai nilai Rsquare pada hasil analisis yaitu sebesar 0,98 sementara 2\% lainnya dipengaruhi oleh variabel lain di luar model regresi yang dilakukan. Sementara, variabel-variabel lainnya yang telah di input namun tidak termasuk pada faktor-faktor yang mempengaruhi memperlihatkan bahwa variabel-variabel tersebut belum secara signifikan mempengaruhi nilai urban compactness Kota Tangerang Selatan dengan nilai signifikasi uji F yang tidak sesuai dengan nilai Probabilitas yaitu sebesar $<0,05$.

Secara sudut pandang teoritis, keempat faktor yang mempengaruhi nilai urban compactness di Tangerang Selatan yaitu kepadatan penduduk, kepadatan lahan terbangun, kepadatan lahan permukiman serta penggunaan kendaraan pribadi sudah mewakilkan prinsip-prinsip utama dari konsep kekompakan ruang. Dapat dilihat pada persamaan regresi, aspek kepadatan penduduk berbanding lurus dengan nilai kekompakan ruang dengan nilai koefisien yang cukup tinggi. Hal ini sesuai dengan karakteristik Kota Tangerang Selatan yang memiliki kepadatan tinggi di beberapa wilayahnya namun tidak diimbangin dengan ketersediaan fasilitas yang merata sehingga timbul gejala sprawling ke pusat-pusat kota seperti Jakarta. Jika kepadatan penduduk diimbangi dengan tersedianya fasilitas dan mudahnya akses pada fasilitas yang lebih dekat tentu konsep kota kompak dapat diterapkan dengan baik.

Faktor kedua yang mempengaruhi kekompakan ruang di Tangerang Selatan adalah kepadatan lahan permukiman dan lahan terbangun. Kepadatan lahan terbangun serta permukiman di Kota Tangerang Selatan dapat mewakili dua indikator utama kota kompak yaitu kepadatan dan penggunaan lahan campuran. Wilayah yang compact dan menerapkan konsep mixed use building maupun mixed use zoning akan lebih baik dalam hal aksesbilitas fasilitas dan lebih efisien dalam bermobilitas dalam wilayah tersebut. Penggunaan lahan campuran juga akan mendorong masyarakat untuk menggunakan sepeda atau berjalan kaki sehingga perencanaan kota yang berkelanjutan dapat terwujud. Selain itu, tingkat intensitas penggunaan lahan di Kota Tangerang Selatan juga mendukung kota ini sebagai kota satelit yang menerapkan konsep kompak, karena kota satelit merupakan lingkungan kota yang mementingkan efisiensi ekonomis seperti halnya konsep penggunaan lahan campuran pada compact city. Penggunaan lahan yang padat dan campuran akan menjadikan penggunaan hal-hal dari aspek ekonomi, sosial serta energi yang lebih efektif dan efisien.

Pada Kota Tangerang Selatan sendiri, terlihat kepadatan lahan terbangun maupun lahan permukiman yang belum merata. Kepadatan pembangunan yang tinggi hanya terlihat pada beberapa kelurahan yang ada pada Kecamatan Ciputat, Ciputat Timur, Pamulang dan Pondok Aren. Sedangkan kelurahan-kelurahan yang ada pada Kecamatan Serpong Utara, Serpong, Setu serta Pondok Aren bagian barat justru memiliki kepadatan yang cenderung rendah. Hal ini dapat diakibatkan karena adanya kawasan-kawasan kota mandiri yang dikembangkan oleh pengembang swasta pada Kecamatan Serpong, Serpong Utara dan Pondok Aren bagian barat. Kawasan tersebut di dominasi oleh tipe perumahan mewah yang cenderung berkepadatan rendah pada area BSD city, Alam sutera dan Bintaro Jaya. Alasan lain yang membuat rendahnya kepadatan lahan terbangun pada kelurahan-kelurahan yang ada pada Kecamatan Setu, Serpong dan Serpong Utara adalah memang masih banyaknya lahan kosong pada wilayah tersebut dikarenakan adanya hutan kota, kawasan golf, area industri dan kawasan penelitian Puspitek pada wilayah tersebut. Sedangkan, untuk area seperti Pamulang dan Ciputat memang hanya memiliki sedikit lahan kosong dan tipe perumahan yang cenderung padat, sehingga kelurahan-kelurahan yang ada seperti Serua, Kedaung dan Pondok Benda memiliki angka kepadatan lahan permukiman dan terbangun yang tinggi pula

Faktor terakhir yang mempengaruhi urban compactness adalah penggunaan kendaraan umum. Pada persamaan regresi penggunaan kendaraan umum di Tangerang Selatan justru memiliki nilai yang berbanding terbalik dengan indeks urban compactness. Fakta bahwa penggunaan kendaraan umum pada Kota Tangerang Selatan berbanding terbalik dengan teori yang mengatakan semakin tinggi nilai kepadatan suatu wilayah maka semakin banyak pengguna kendaraan umum pada wilayah tersebut dapat dikarenakan beberapa hal, seperti tingginya angka kepadatan namun masih kurangnya keinginan masyarakat untuk menggunakan kendaraan umum yang tersedia karena minimnya kualitas dan waktu tempuh yang panjang. Selain itu, konsep pengompakan ruang memang dapat mengurangi penggunaan kendaraan bermotor dan mengurangi masa perjalanan, namun konsep compact city tidak dapat menghapus kebutuhan akan kendaraan pribadi akan kebutuhan tertentu. Untuk itu diperlukan moda transportasi umum yang lebih baik guna mendukung pemadatan wilayah dan konsep pengompakan ruang di Kota Tangerang Selatan. 


\section{KESIMPULAN}

Berdasarkan keseluruhan hasil analisa penelitian, karakteristik kekompakan ruang di Tangerang Selatan memiliki sifat yang berbeda-beda pada tiap kelurahannya. Sedangkan, berdasarkan hasil perhitungan analisis regresi terdapat empat faktor yang mempengaruhi angka urban compactness di Kota Tangerang Selatan yaitu kepadatan penduduk, kepadatan lahan terbangun, kepadatan lahan permukiman, tingkat penggunaan kendaraan umum. Tingkat kepadatan yang tinggi di Tangerang Selatan didominasi oleh area-area permukiman padat penduduk sedangkan, permukiman yang dikembangkan oleh developer swasta memiliki tingkat kepadatan yang cenderung rendah. Secara keseluruhan tingkat penggunaan kendaraan umum di Tangerang Selatan juga masih dapat dikatakan rendah. Sehingga dapat disimpulkan keempat faktor tersebut dapat menjadi acuan untuk mengoptimalkan pengembangan konsep compact city di Tangerang Selatan.

\section{DAFTAR PUSTAKA}

[1] M. Jenks, E. Burton, and K. Williams, The Compact city: a sustainable urban form? New York : E \& FN Spon, 1996.

[2] H. Aprianto, E. Eriyatno, E. Rustiadi, and I. Mawardi, "Model kebijakan pengembangan kota Tangerang Selatan menuju kota berkelanjutan,” J. Sos. Ekon. Pekerj. Umum, vol. 7, no. 2, pp. 91103, Jul. 2015

[3] OECD, Compact city policies: A comparative assesment. OECD Publishing, 2012.

[4] G. B. Dantzig and T. L. Saaty, Compact city; a plan for a liveable urban environment. San Francisco, California: W.H. Freeman, 1973.

[5] M. S. Roychansyah, "Inovasi : media komunikasi sains dan teknologi.,” INOVASI, vol. 7, no. XVIII, pp. 19-27, 2006.

[6] D. Stathakis and G. Tsilimigkas, "Applying urban compactness metrics on Pan-European datasets," in 29th Urban Dato Management Symposium (Volume XL-4/W1), 2013, pp. 127-132. 